\title{
Climate change and oak growth decline: Dendroecology and stand productivity of a Turkey oak (Quercus cerris L.) old stored coppice in Central Italy
}

\author{
Alfredo Di FILIPPO ${ }^{1}$, Alfredo AlessANDRINI ${ }^{1}$, Franco BIONDI $^{2}$, Silvia BlAsi $^{1}$, Luigi PorToghesi $^{3}$, \\ Gianluca PIOVESAN ${ }^{1 *}$ \\ ${ }^{1}$ DendrologyLab, DAF, Università degli Studi della Tuscia, Viterbo, Italy \\ ${ }^{2}$ Dendrolab, University of Nevada, Reno, USA \\ ${ }^{3}$ DISAFRI, Università degli Studi della Tuscia, Viterbo, Italy
}

(Received 21 August 2009; accepted 23 February 2010)

Keywords:

climate change /

oak decline /

stem analysis /

stored coppice /

tree-ring

\begin{abstract}
- We combined stem volume increment analysis with dendroecological tools to address two unresolved issues concerning oak dieback in Mediterranean areas: early detection of changes in stand growth, and identification of mechanisms for observed growth declines.

- We reconstructed productivity of a stored coppice formed by Turkey oak (Quercus cerris) to test if its growth decline was linked to climatic variability, while also accounting for age-related and sociological factors.

- Drought in May-June and in prior-year late summer-autumn was negatively correlated with current growth during 1974-2006. Previous November water balance was the strongest signal. Moving Correlation Functions (11 y windows) indicated that the May-June signal remained dominant until 1996, thereafter falling to non-significant values in parallel with the May-June water balance drying trend; at the same time the previous autumn correlations reached significant values. Since 1994 there was a two-year lagged response to June water balance, suggesting that, when growth declined, loss of current-year climate signals was accompanied by the emergence of previous-year ones.

- Growth and productivity of deciduous oaks in Mediterranean environments is linked to late springearly summer hydrologic balance; at both annual and decadal timescales, oak growth decline was associated with a delayed response to climate.
\end{abstract}

\section{INTRODUCTION}

In the next few decades the Mediterranean Basin could face considerable changes in climate (e.g., Nogués Bravo et al., 2008; Parry et al., 2008). Atmospheric warming and reduced precipitation are expected to exacerbate drought conditions and strongly influence regional water balances (Mariotti et al., 2008). Water shortage in forest ecosystems is not only the most likely cause of inter-annual changes in primary productivity, but may also compromise tree health and survival (Bréda et al., 2006; Van Mantgem et al., 2009). If forest ecosystems become affected by climatic shifts, their services and economic values may be at risk (Kirilenko and Sedjo, 2007; Schröter et al., 2005) with regard to wildlife (such as mast production), timber (because of degraded value or lower sustainable yields), and recreation (including visual attractiveness).

To understand concurrent and delayed consequences of increased frequency and/or intensity of drought episodes, observations are needed at multiple temporal scales (Allen, 2009;

* Corresponding author: piovesan@unitus.it
Breda et al., 2006). Although several studies have been conducted on long-term climatic change impacts in Europe (Kahle et al., 2008; Rosenzweig et al., 2008), the Mediterranean Basin has received relatively less attention (Piovesan et al., 2008). When permanent plot data are lacking, forest growth dynamics and its controlling factors can be analyzed using a dendroecological approach (e.g. Biondi, 1999; Metsaranta and Lieffers, 2009). A few such studies have recently focused on the long-term impact of climate variations on forest productivity in Mediterranean mountains, showing the adverse effects of drought conditions on beech ecosystems (Jump et al., 2006; Piovesan and Schirone, 2000; Piovesan et al., 2008). Since bioclimatic position (Di Filippo et al., 2007; Piovesan et al., 2005) or biome type (Nahm et al., 2006) determine the local or regional response to large-scale climatic stress, it is particularly important to investigate productivity trends with dendroecological methods at lower elevations (hills, valleys) as well (e.g. Sarris et al., 2007).

Throughout the Italian Peninsula, hillslopes are often characterized by oak and chestnut coppices, a form of forest 
management with a long history of application (Ciancio and Nocentini, 2004). Yield tables for this widespread landscape unit were developed using a space for time approach, without including the effect of climatic variability on tree and forest productivity. In addition, the shorter rotation and maturation of coppices compared to seed-regenerated forests has not been conducive to the establishment of permanent plots and the consequent analysis of long-term population dynamics. In the last decades, reduced population pressure has allowed several hardwood stands in the Italian countryside to transition from coppice to high-forest management. At the same time, some oak stands composed of Turkey oak (Quercus cerris L.) and downy oak (Quercus pubescens Willd.) have experienced growth and health decline since the beginning of the 1980s, especially when managed as stored coppices (Amorini et al., 1996; Desprez-Loustau et al., 2006).

Two unresolved issues concerning oak dieback in Mediterranean areas are early detection of changes in tree and forest growth, and determination of the causes of observed growth declines. Stem volume increment analysis, which is considered the best tool for assessing forest decline mechanisms (e.g. Le Blanc, 1990), has to date been rarely applied to calculate oak productivity losses (Standovár and Somogyi, 1998), but without addressing potential climatic causes. We combined stem volume increment analysis with dendroecological tools to address these issues. Pathological and dendroecological studies, together with assessments of forest stand dynamics and structural aspects, have highlighted the role of a dry spell for initiating several processes leading to oak decline in Italy (Amorini et al., 1996; Ragazzi et al., 2002; Vannini and Valentini, 1994). However, drought can have multiple impacts on deciduous oaks (e.g. Planchon et al., 2008), hence more information is required on seasonality influences for accurate ecological modeling and to differentiate the controlling mechanisms exerted by inter-decadal climatic modes (Hurrell, 1995; Mariotti et al., 2005; Piovesan et al., 2008). Our specific objective was to reconstruct productivity (i.e., annual volume increment) of old coppice stands (stored coppice) formed by Turkey oak to test if the observed oak decline (Anselmi et al., 2008) can be related to growth reductions and linked to climatic variability, while also accounting for temporal changes in stand structure. We calculated volume increment because it is particularly adept at quantifying climate impacts on productivity trends of relatively young individuals and populations (Le Blanc, 1990).

\section{MATERIALS AND METHODS}

\subsection{Study area}

The current landscape of Monti della Tolfa is characterized by forests (about 3500 ha) dominated by oak coppices regularly cut based on a 16-18 y rotation cycle. Our study was performed in a stored coppice (i.e., a coppice that has been left to grow beyond its normal rotation cycle) with standards (scattered individual stems that remained uncut through several coppicing cycles) located on the $\mathrm{N}$ NE slope of Monte Piantangeli ( $\left.42^{\circ} 11^{\prime} 08^{\prime \prime} \mathrm{N} ; 11^{\circ} 57^{\prime} 58^{\prime \prime} \mathrm{E}\right)$, near
Tolfa, in the Rome province, Italy (Fig. 1). In the 1970s the study area was set aside for environmental and recreational purposes.

The volcanic bedrock is made of trachytic lavas, which gave place to andisols classified as Xeroumbrept andic (Alessandrini et al., 2008). These soils are acid, rich in organic matter, with a low percent base saturation due to leaching. The forest cover is dominated by Turkey oak (Quercus cerris L.), with other broadleaved species occurring generally as few, small individuals: downy oak (Quercus pubescens Willd.), maples (Acer monspessulanum L., Acer campestre L., Acer opalus Miller), manna ash (Fraxinus ornus L.), hop hornbeam (Ostrya carpinifolia Scopoli) and European hornbeam (Carpinus betulus L.), true and wild service trees (Sorbus domestica L. and S. torminalis (L.) Crantz). The forest can be ascribed to the phytosociological association Melico uniflorae-Quercetum cerridis Arrigoni (Arrigoni, 1998), typical of Tuscany and northern Latium hills and mountains with deep soils.

Past land use history, besides logging, has included open-range grazing, which is traditionally employed in the Maremma countryside under a system of communal ownership dating back to Medieval times and called "Università Agraria".

\subsection{Field sampling}

The study area is representative of Turkey oak stored coppices with advanced decline phenomena, a frequent forest type in Latium (e.g. Amorini et al., 1996). Phytopathological surveys of this stand revealed approximately $27 \%$ dead stems, of which $\sim 87 \%$ with Biscogniauxia mediterranea stromata (Anselmi et al., 2008). Additional field observations indicated the presence of root rot (Armillaria sp.), insect galleries (Agrillus sp.), and other fungi (Phomopsis sp., Phusarium sp.). Of live oak stems, $28 \%$ had cortical necrosis ( $4 \%$ had Biscogniauxia stromata) and only $40 \%$ was considered healthy.

In winter 2007 the study area was subjected to silvicultural treatments consisting of small clearcut areas (about $700 \mathrm{~m}^{2}$ ) to evaluate the capacity of Turkey oak to resprout or survive as new seedlings in the gaps. Two study plots with N-NE exposure were chosen at the base and at the top of the stored coppice to represent the stand average conditions (Fig. 1): the upper plot (UP) covered $756 \mathrm{~m}^{2}$ at $475 \mathrm{~m}$ asl with a slope of $44 \%$; the lower plot (LP) covered $685 \mathrm{~m}^{2}$ at about $450 \mathrm{~m}$ asl with a $33 \%$ slope.

Within each plot we measured diameter at breast height $(\mathrm{DBH}$; $1.3 \mathrm{~m}$ above the ground) of stems with $\mathrm{DBH}>2.5 \mathrm{~cm}$. We sampled the heights of several Turkey oak stems in each $5 \mathrm{~cm}-\mathrm{DBH}$ class (in total 37 heights measured at UP and 21 at LP) to build heightDBH curves. Stem volume was computed using the two-way table by Bianchi and La Marca (1984), developed for Turkey oak coppices of the Viterbo province, growing on volcanic soils and located about $50 \mathrm{~km}$ N-NE from Monte Piantangeli.

Within each plot we sampled 30 oaks for stem analysis following Hartig's method to stratify the sampling for biomass studies (La Marca, 2004). All stems with $\mathrm{DBH} \geq 7.5 \mathrm{~cm}$ were ordered according to DBH and divided into three groups of equal basal area (BA), then 10 trees were randomly selected in each BA group for stem analysis. This method concentrates the sampling effort on larger trees, which hold most of the stand biomass, and discounts smaller stems, which, although more abundant, are usually suppressed and account for a small percentage of stand productivity. Hartig's method is thus a stratified sampling procedure that reduces estimation error of stand total volume increment (VI) by under-/oversampling DBH classes according to their contribution to the stand VI (La Marca, 2004). The three 


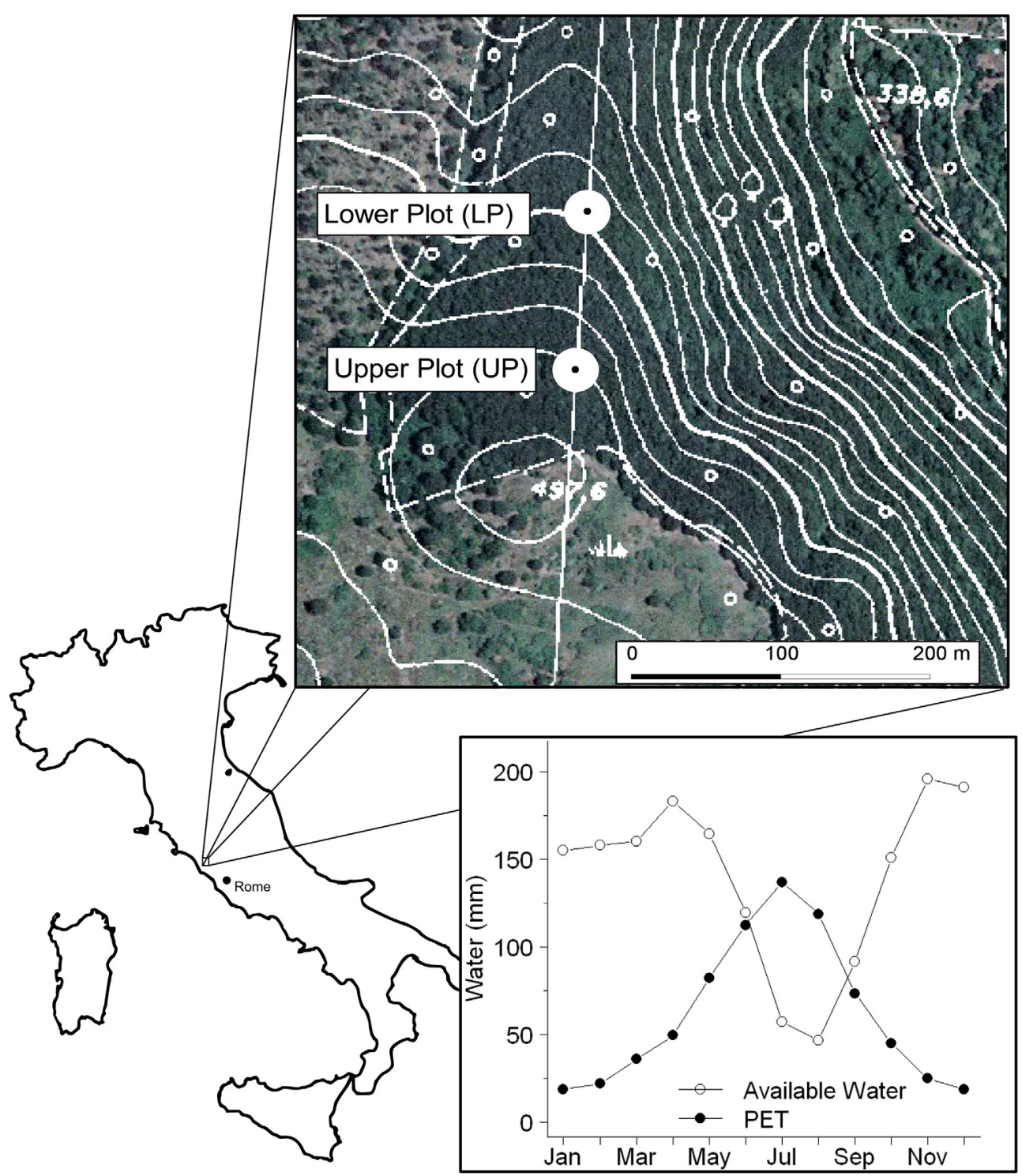

Figure 1. The geographic location of Monte Piantangeli with the position of the 2 study plots. Lower right box: the study site water balance (period: 1974-2006), represented by monthly potential evapotranspiration (PET) and available water (current month precipitation + previous month soil storage).

BA groups were, from smaller to larger, UP1, UP2 and UP3 in the Upper Plot; LP1, LP2 and LP3 in the Lower Plot. Full cross-sections were taken along each selected stem, from the base every $2 \mathrm{~m}$, following the main branch up to a diameter of $3 \mathrm{~cm}$. A cross-section was also cut from each stem at $1.3 \mathrm{~m}$ from the ground for comparing growth patterns at a standard height.

\subsection{Laboratory and numerical analysis}

All disks were surfaced using progressively finer sandpaper until all rings were clearly visible. On each disk we measured tree-ring width on four radii, the first two following the longest diameter, and the remaining two along the orthogonal diameter. The four crossdated radii, whose dating was checked by standard dendrochronological techniques (Stokes and Smiley, 1996), were averaged to form a mean disk tree-ring series. All mean disk series of a stem, representative of radial growth at different heights along the stem, were used to calculate the annual stem volume increment using the package "tReeglia" (Bascietto and Scarascia Mugnozza, 2004) of the software R (R Development Core Team, 2005). This program interpolates tree heights at different ages using the Carmean algorithm to yield past pseudoannual estimates of tree height. Stem volume at each age is computed using Smalian's (or trapezium) formula, and volume increment is the difference of consecutive stem volumes. Different descriptors of growth as a function of age were thus produced for each tree: the ringwidth series for each disk, with particular attention to that at breast height (RW); the basal area increment (BAI); and the volume increment (VI). The 10 VI series of stems sampled within each BA group were averaged into a group mean VI chronology $\left(\mathrm{MVI}_{\mathrm{g}}\right.$, in $\left.\mathrm{dm}^{3} \mathrm{y}^{-1}\right)$. 
For both the UP and LP plots, each of the $3 \mathrm{MVI}_{\mathrm{g}}$ was multiplied by the group density (in stem ha ${ }^{-1}$ ) to obtain the total group VI $\left(\mathrm{TVI}_{\mathrm{g}}\right.$, in $\mathrm{m}^{3} \mathrm{ha}^{-1} \mathrm{y}^{-1}$ ).

Stem analysis underestimates volume increment because ring width is measured inside bark, and only on cross-sections of the main stem (smaller branches are not included). Thus, a correcting factor was applied to the individual VI series of each group to make the cumulative $\mathrm{TVI}_{\mathrm{g}}$ equal to the group volume outside bark obtained by the two-way table. In the end, each plot total VI (TVI) chronology, representing the annual variations of stand productivity, was built by summing the $3 \mathrm{TVI}_{\mathrm{g}}$ chronologies. Because we used present-day density data, TVI was reconstructed since the time of last coppicing. In order to quantify growth variations by tree age, we built cohort mean $\mathrm{VI}\left(\mathrm{MVI}_{\mathrm{c}}\right)$ chronologies by averaging the VI of trees having the same age within each plot. We also produced a mean VI (MVI) chronology, representative of the average tree growth in each plot. The same types of chronologies made for VI were developed for basal area increment: $\mathrm{MBAI}_{\mathrm{g}}, \mathrm{TBAI}_{\mathrm{g}}, \mathrm{TBAI}, \mathrm{MBAI}_{\mathrm{c}}, \mathrm{MBAI}$. We studied VI and BAI lower frequency variations by interpolating their chronologies with an 11-y cubic smoothing spline (Cook and Peters, 1981).

A prewhitened version of each mean volume increment (VI) chronology was obtained according to the formula reported in Piovesan et al. (2008). Each series was fit by a cubic smoothing spline with a $50 \%$ frequency response to $67 \%$ of the series length (Cook and Kairiukstis, 1990); the standardized series were averaged to form a standardized chronology, prewhitened by autoregressive modeling. The autoregressive operator of order $p$ was chosen according to multiple criteria described by Biondi and Swetnam (1987). The program ARSTAN was used for computations (Cook and Holmes, 1986), and all chronologies were evaluated by the expressed population signal (EPS) using the 0.85 threshold (Wigley et al., 1984). The same formula was applied to ring-width (RW) and basal area increment (BAI), so that we obtained MVI, MBAI and MRW prewhitened chronologies for each plot. For VI and within each plot, we prewhitened chronologies for each BA group $\left(\mathrm{MVI}_{\mathrm{g}}\right)$ and each cohort $\left(\mathrm{MVI}_{\mathrm{c}}\right)$.

We considered monthly and seasonal climate variables as potential controlling factors on tree growth. Climate data were obtained from the $1 \times 1^{\circ}$ gridded dataset developed by Brunetti et al. (2006) over all of Italy for mean monthly temperature anomalies and precipitation ratios, both calculated taking as reference the average of the period 1961-1990. Grid values for the cell containing Monte Piantangeli were converted into measurements by adding (for temperature) or multiplying (for precipitation) the 1961-1990 averages from the nearby station of Vigna di Valle $\left(42^{\circ} 04^{\prime} 60^{\prime \prime} \mathrm{N}\right.$; $\left.12^{\circ} 13^{\prime} 00^{\prime \prime} \mathrm{E}\right)$. Since Vigna di Valle is at $270 \mathrm{~m}$ asl, the average monthly temperature for Monte Piantangeli (elevation: $462.5 \mathrm{~m}$ asl) was adjusted considering a reduction of $0.54{ }^{\circ} \mathrm{C} / 100 \mathrm{~m}$ of increasing elevation (Claps et al., 2008). Monte Piantangeli drought was then expressed as Thorntwaite monthly Water Balance (WB; calculated by the USGS software: http://www.brr.cr.usgs.gov/projects/ SW_MoWS/software/thorn_s/thorn.shtml), which computes the various components of the hydrological cycle (McCabe and Markstrom, 2007 ). For the month $i$ of each year, WB (in mm of water) was calculated according to the formula:

$$
\mathrm{WB}_{i}=\left(P_{i}+\mathrm{ST}_{i-1}\right)-\mathrm{PET}_{i}
$$

where $\mathrm{P}_{i}=$ monthly precipitation, $\mathrm{ST}_{i-1}=$ previous month soil moisture storage, $\mathrm{PET}_{i}=$ monthly Potential Evapotranspiration. The soil storage capacity $(93 \mathrm{~mm})$, needed for calculations, was derived by means of Salter's formula (Salter \& Williams, 1967) using texture and depth data for each soil horizon (Alessandrini et al., 2009). The water balance diagram (Fig. 1) summarizes the climatic features of the study area, characterized by July-August drought stress.

Growth-climate relationships were quantified over the period common to all chronologies using correlation function (CF) and response function (RF) analyses (Biondi and Waikul, 2004). Current year VI, BAI or RW were matched against monthly mean temperature, total precipitation, and water balance of the current $(t)$ and previous year (up to May of $t-1$ ). We also analyzed the spring and summer climate of two years before, when floral induction takes place, because mast seeding can influence tree growth (Piovesan and Adams, 2005). The bootstrap method (Efron and Tibshirani, 1986; Guiot, 1991) was used for significance testing. Bootstrapped Moving Correlation/Response Functions (MCFs/MRFs) were used to reveal temporal changes of growth-climate relationships (Biondi and Waikul, 2004) considering an 11-y moving window. Significant and adjacent monthly variables, controlling growth in the same way within/between plots, cohorts and BA groups, were grouped to produce climatic factors linked to tree growth over a whole season. MCF/MRF analyses were performed on these grouped monthly variables, too. Decadal climate-tree growth relationships were investigated by means of 11-y smoothed versions of the VI and BAI chronologies and of climatic factors, chosen according to their importance in $\mathrm{CF} / \mathrm{RF}$ analyses (Piovesan et al., 2008). We compared the current volume increment (defined as "present-day" or "current" in the text) with the most recent growth maximum ("peak" in the text) to quantify productivity differences and test their link to the recent dry phase. Furthermore, we analyzed growth variations of cohorts and BA groups in the two plots to evaluate the impact of climate fluctuations on growth decline processes across different levels of stand organization.

Finally, we applied Moving Correlation Function (MCF) analysis to a Quercus cerris BAI chronology from Manziana, a high-forest about $14 \mathrm{~km}$ SE of Monte Piantangeli and located at $350 \mathrm{~m}$ asl (Agrimi et al., 1991). We sampled this forest in 2001 by taking one core from 9 dominant trees, and we obtained a site BAI chronology, which was EPS-validated for the period 1894-2001. The Manziana Turkey oak high-forest grows on a flat area under climatic and pedological conditions similar to those of Monte Piantangeli (Plutino, 2006). The two forests, although resulting from different sylvicultural systems (high-forest vs. coppice), have in common the dominant species (Turkey oak), the prevailing even-aged structure, the overstocking due to the lack of management for more than $30 \mathrm{y}$, and the abundance of dead or decaying trees as a result of the Biscogniauxia attacks (Plutino, 2006).

\section{RESULTS}

\subsection{Stand structure and productivity}

The two plots, upper and lower, had similar basal area and volume (Tab. I), and showed a bell-shaped stem frequency distribution by diameter class (see Fig. S1, supplementary material available online only at www.afs-journal.org). However, LP was characterized by higher density and smaller stem dimensions as shown by mean DBH (UP: $20.2 \pm 8.1 \mathrm{~cm}$; LP: $19.6 \pm 6.5 \mathrm{~cm}$ ), maximum DBH (UP: $39 \mathrm{~cm} ;$ LP: $32 \mathrm{~cm}$ ) and mean height (Tab. Ia). Minimum height was equal to 5-8 m, while maximum height was about $20 \mathrm{~m}$ in UP and $19 \mathrm{~m}$ in LP. 
Table I. (a) Structural attributes of the two study plots and (b) the tree sampling according to the three basal area groups (trees with DBH $<7.5 \mathrm{~cm}$ excluded).

\begin{tabular}{lccccc}
\hline (a) & Density & $\begin{array}{c}\text { Basal } \\
\text { area } \\
\left(\mathrm{m}^{2} \mathrm{ha}^{-1}\right)\end{array}$ & $\begin{array}{c}\text { Mean } \\
\text { height } \\
(\mathrm{m})\end{array}$ & $\begin{array}{c}\text { Cohort 1959 } \\
\text { stature } \\
(\mathrm{m})\end{array}$ & Volume \\
\cline { 2 - 6 } & $\left({\left.\mathrm{stem} \mathrm{ha} \mathrm{h}^{-1}\right)}^{3} \mathrm{ha}^{-1}\right)$ \\
\cline { 2 - 6 } Upper plot & 794 & 29 & 14.7 & 18.4 & 230 \\
Lower plot & 891 & 30 & 14.5 & 18.2 & 231 \\
\hline
\end{tabular}

Stature $=$ mean height of the 4 tallest trees.

\begin{tabular}{|c|c|c|c|c|c|c|c|c|c|}
\hline \multirow[t]{3}{*}{ (b) } & \multicolumn{9}{|c|}{ Basal area group sampling } \\
\hline & \multirow[t]{2}{*}{ Group } & \multirow[t]{2}{*}{$\begin{array}{c}\% \text { of total } \\
\text { stems }\end{array}$} & \multirow[t]{2}{*}{$\begin{array}{c}\% \text { of group } \\
\text { stems sampled }\end{array}$} & \multirow[t]{2}{*}{$\begin{array}{c}\text { Mean * } \\
\text { diameter }(\mathrm{cm})\end{array}$} & \multirow[t]{2}{*}{$\begin{array}{c}\text { Mean } \dagger \\
\text { Height }(m)\end{array}$} & \multirow[t]{2}{*}{$\begin{array}{c}\text { Mean } \dagger \\
\text { Volume }\left(\mathrm{m}^{3}\right)\end{array}$} & \multicolumn{3}{|c|}{$\begin{array}{c}\text { Cohorts present } \\
(n \text { stems })\end{array}$} \\
\hline & & & & & & & 1945 & 1959 & 1972 \\
\hline \multirow{3}{*}{$\begin{array}{l}\text { Upper plot } \\
\text { (UP) }\end{array}$} & UP1 & 50 & 33 & $17.3(10-21)$ & $13.9 \pm 1.4$ & $0.17 \pm 0.06$ & - & 3 & 7 \\
\hline & UP2 & 27 & 63 & $24.4(22-26)$ & $16.4 \pm 0.3$ & $0.38 \pm 0.04$ & 1 & 6 & 3 \\
\hline & UP3 & 17 & 100 & $31.0(26-39)$ & $18.0 \pm 0.9$ & $0.69 \pm 0.23$ & - & 8 & 2 \\
\hline \multirow{3}{*}{$\begin{array}{l}\text { Lower plot } \\
\text { (LP) }\end{array}$} & LP1 & 41 & 40 & $18.5(15-20)$ & $14.5 \pm 0.6$ & $0.19 \pm 0.04$ & - & 10 & - \\
\hline & LP2 & 30 & 56 & $22.5(21-24)$ & $15.9 \pm 0.3$ & $0.31 \pm 0.04$ & - & 10 & - \\
\hline & LP3 & 20 & 83 & $28.6(25-32)$ & $17.2 \pm 0.5$ & $0.51 \pm 0.09$ & 3 & 7 & - \\
\hline
\end{tabular}

$*$ Range in parentheses; ${ }^{\dagger}$ mean \pm standard deviation.

Most stems belonged to the 20-25 cm DBH classes, which contained almost $50 \%$ of trees and BA in UP, $66 \%$ trees and $76 \%$ BA in LP. Turkey oak dominates both plots, with other species limited to smaller diameter classes and representing less than 5\% BA. At the lower plot (LP), few individuals of maples and manna ash reached $15-20 \mathrm{~cm}$ DBH. The heightDBH function was represented by a semi-logarithmic curve (Fig. S2). Individual tree volume obtained by cumulating VI was on average $11 \pm 19 \%$ (UP) and $13 \pm 15 \%$ (LP) less than the volume given by the two-way table because VI was measured inside bark and considered only the main branch, while the table represented total tree volume outside bark.

At both plots, the BA groups accounting for $10 \mathrm{~m}^{2} \mathrm{ha}^{-1}$ were sampled with different intensity. Groups with larger trees (UP3, LP3) were sampled almost totally, while a progressively lower percentage of stems was sampled according to average dimensions (Tab. Ib). The BA groups reflected volume partition within the stand, since almost one third of total volume was held by each group. Mean volume almost doubled passing from one group to the other (especially at UP). Height too was significantly linked to BA group, with about $1.5 \mathrm{~m}$ difference in mean group height ( $t$-test $p<0.001)$, except for UP1, which was $2.5 \mathrm{~m}$ less than UP2.

Tree-ring analysis revealed the existence of three age cohorts at UP (1945: 1 tree; 1959: 17 trees, 1972: 12 trees) and 2 at LP (1945: 3 trees; 1959: 27 trees) (Tab. Ib), corresponding to a coppice rotation length of 13-14 y (1944-1945, 1958-1959, 1971-1972). The last logging did not occur at LP, which included three 1945 standards in the larger trees group. The 1972 and 1959 cohorts made up an almost equal amount of the upper plot, with the 1972 cohort having mostly small stems (UP1), while the 1959 cohort had abundant medium and large stems (Tab. I). Only one 1945 standard was found in group UP2.

The upper plot included standards with higher biomass than the lower one. At UP, almost $60 \%$ of present trees
(476 stem $\mathrm{ha}^{-1}$ ) were there before the 1971-1972 logging, accounting at that time for $14.8 \mathrm{~m}^{3} \mathrm{ha}^{-1}$ of volume and $3.94 \mathrm{~m}^{2} \mathrm{ha}^{-1}$ of basal area (BA): thus, $13 \%$ of total present-day BA was already present. At LP, the 3 present-day standards ( 89 stem ha ha $^{-1}$, only $10 \%$ of present-day stems) originated in 1945: after the last logging (1958-1959), they accounted for $1 \mathrm{~m}^{3} \mathrm{ha}^{-1}$ of volume and $0.25 \mathrm{~m}^{2} \mathrm{ha}^{-1}$ of BA. TVI at LP had a first peak in increment at the beginning of the 1980s (almost 35 y after coppicing), stabilizing afterwards (with some oscillations) up to 1997 , when a second peak occurred. After 1997, a negative growth trend began (Fig. 2). At the upper - and younger - plot, growth increment increased until it reached a peak in 1992-1997, but declined similarly to LP afterwards. When presenting increment data we will refer to "peak" growth as the average of the 1995-1999 period (central year: 1997), "current" or "present-day" growth as the average of the 2002-2006 period (central year: 2004).

Stand productivity (Fig. 2a and Tab. IIa) and average tree growth ("All trees" MVI in Tab. IIb) were considerably higher at UP than LP during both peak and current period. This difference can be mainly explained by the younger age of the UP coppice caused by logging in 1972. In fact, although trees reached taller heights at UP, the hyphotesis of a higher soil fertility there is not corroborated by the mean height of the 4 tallest stems of the 1959 cohort (stature; Tab. Ia). At both plots, $1 / 3$ of TVI has been lost from the peak period to date, resulting in a decrease of about 3 (UP) and 2 (LP) $\mathrm{m}^{3} \mathrm{ha}^{-1} \mathrm{y}^{-1}$, mostly because of peak-to-current MVI reduction (Tab. IIb). The three BA groups contributed similarly to TVI, even though group one accounted for slightly less (Fig. 1). Groups 2-3, where standards were more frequent, accounted for the majority of total volume increment in the first 5-10 y after logging (data not shown). Mean group volume increment $\left(\mathrm{MVI}_{\mathrm{g}}\right)$ resembled TVI (Fig. 2b), but growth rates were proportional to tree dimension (Tab. IIb). In fact, peak $\mathrm{MVI}_{\mathrm{g}}$ increased 
Table II. (a) Total volume increment (TVI) and (b) Mean volume increment (MVI) matched between peak (1995-1999) and current (2002-2006) periods among different groupings of trees in each stand. Different superscript letters indicate significant pairwise tests along rows or columns.

\begin{tabular}{lrrr}
\hline (a) & \multicolumn{3}{c}{ TVI $\left(\mathrm{m}^{3} \mathrm{ha}^{-1} \mathrm{y}^{-1}\right)$} \\
\cline { 2 - 4 } & Peak & Current & \% loss \\
\cline { 2 - 3 } UP & 8.4 & 5.6 & -33 \\
LP & 6.6 & 4.3 & -35 \\
\hline
\end{tabular}

\begin{tabular}{|c|c|c|c|}
\hline \multirow[t]{3}{*}{ (b) } & \multicolumn{3}{|c|}{ MVI $\left(\mathrm{dm}^{3} \mathrm{y}^{-1}\right)$} \\
\hline & Peak & Current & $\%$ loss \\
\hline & \multicolumn{3}{|c|}{ All trees } \\
\hline UP & $12.0^{a}$ & $7.9^{\mathrm{c}} t^{* \star *}$ & -34 \\
\hline LP & $8.1^{b}$ & $5.4^{\mathrm{d}} t^{* \star *}$ & -33 \\
\hline
\end{tabular}

\begin{tabular}{|c|c|c|c|}
\hline \multirow[b]{2}{*}{ UP1 } & \multicolumn{3}{|c|}{ Basal Area Groups $\left(\mathrm{MVI}_{\mathrm{g}}\right)$} \\
\hline & $7.1^{\mathrm{a}}$ & $5.0^{\mathrm{d}} t^{* \star \star}$ & -30 \\
\hline UP2 & $11.2^{b}$ & $6.7^{\mathrm{e}} t^{* \star \star}$ & -40 \\
\hline UP3 & $17.7^{c}$ & $12.2^{\mathrm{f}} t^{* * *}$ & -31 \\
\hline & $\mathrm{H}_{c}{ }^{*}$ & $H_{c}{ }^{*}$ & \\
\hline LP1 & $5.1^{a}$ & $3.2^{\mathrm{d}} t^{* \star \star}$ & -38 \\
\hline LP2 & $8.2^{b}$ & $5.8^{\mathrm{e}} t^{* \star *}$ & -29 \\
\hline LP3 & $10.9^{c}$ & $7.1^{\mathrm{f}} \mid t^{\star \star \star}$ & -35 \\
\hline
\end{tabular}

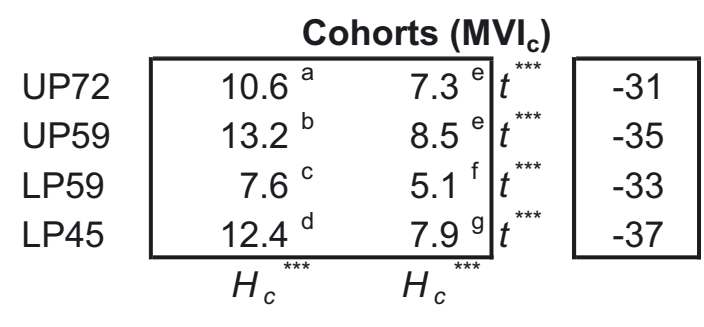

Reference period peak $=(1995-1999)$; Current $=(2002-2006)$.

$t=$ paired $t$-test $H_{c}=$ Kruskal-Wallis test.

Significance level *: $p<0.05 ; * *: p<0.01 ; * * *: p<0.001$.

by $\sim 60 \%$ from smaller to larger groups, except for the LP3LP2 difference $(+33 \%)$. Peak MVI $\mathrm{g}_{\mathrm{g}}$ was higher in UP than LP (Tab. IIb), and peak-to-current $\mathrm{MVI}_{\mathrm{g}}$ reduction was proportional to VI level within each BA group, so that a similar (30-40\%) VI decrease was found for all BA groups (Tab. IIb). Similarly, older cohorts at both plots grew faster but lost more increment in recent times, considering mean cohort volume increment $\left(\mathrm{MVI}_{\mathrm{c}}\right.$, Tab. IIb). For example at UP, where the 1959 (UP59) and 1972 (UP72) cohorts were almost equally repre- sented, UP59 peak growth was $25 \%$ higher with respect to UP72, while their current growth is similar. As for all trees and BA groups, the peak-to-current VI loss was about $1 / 3$. The 1959 cohorts at UP (UP59) and LP (LP59) showed a consistent pattern from peak to present-day growth, since UP59 exceeded LP59 by about 70\% during both peak and current periods.

\subsection{Dendroecological relationships}

All tree-ring chronologies (Tab. S1 supplementary material available online only at www.afs-journal.org) were based on samples with adequate common year-to-year variability (EPS > 0.85) during 1960-2006 (1972-2006 for UP72). In all cases, a first-order autoregressive model was chosen for prewhitening. Within each plot, MVI, MBAI and MRW prewhitened chronologies were highly correlated (Tab. S2a). For the common period 1974-2006, principal component analysis revealed that PC1 of MVI, MBAI and MRW chronologies accounted for $94.9 \%$ variance. High correlation was also present among $\mathrm{MVI}_{\mathrm{g}}$ and $\mathrm{MVI}_{\mathrm{c}}$ chronologies (Tab. S2b). The highest BA group correlations were those between groups 2 and 3. Among cohorts, UP59 correlated more to LP59 $(r=$ $0.98)$ than to UP72 ( $r=0.89)$, suggesting the existence of an age-related climatic signal between stands (Tab. S2c).

Correlation functions (CF) with climatic variables were computed using the 1974-2006 common period for all MRW, MBAI, and MVI chronologies. Because of high similarity between results for MRW, MBAI, and MVI, only results for MVI are presented (Figs. 3-4). Considering all trees in a plot, drought in May-June and in prior-year October-November and August were negatively correlated with current growth. In both plots the strongest monthly signal, i.e. previous November water balance followed by June water balance, were confirmed by response functions (not shown). A negative correlation with April temperature could be related to late-season frost damage after a precocious leaf formation following warm spring days (Dittmar et al., 2006). Key monthly water balance variables grouping gave a slight increase in correlation: MayJune (UP: $r=0.38$; LP: $r=0.41$; in both cases, bootstrapped $p<0.05$ ); previous October-November (UP: $r=0.52$; LP: $r=0.49$; in both cases, bootstrapped $p<0.05)$. Tree dimension and age influenced CF results (Figs. 3 and 4): April climate weighted more for larger, older, trees, presumably because larger crowns are more exposed to frost damage. While larger/older stems depended on previous October-November and current May-June factors, smaller/younger stems (UP1 and LP1) response was limited to previous November and current June.

Moving Correlation and Response Functions (MCFs and MRFs) results agreed, and indicated that the main climatic signals, i.e. water balance during current May-June and previous October-November, fluctuated during the coppice history (Fig. 5; UP and LP showed the same behavior, so only LP results were presented). At decadal scales, the May-June signal remained dominant until 1996, thereafter falling to nonsignificant values in parallel with the May-June water balance trend, while at the same time the previous autumn correlations 
(a)

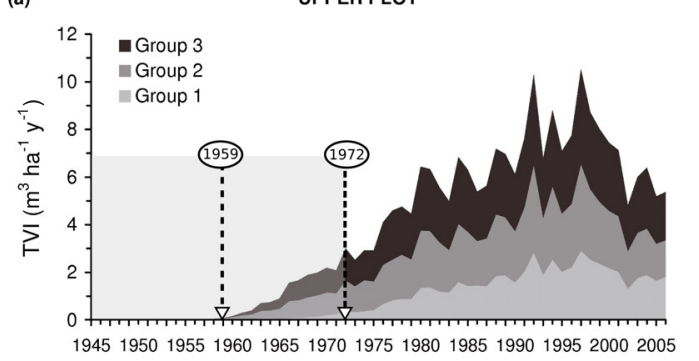

(b)

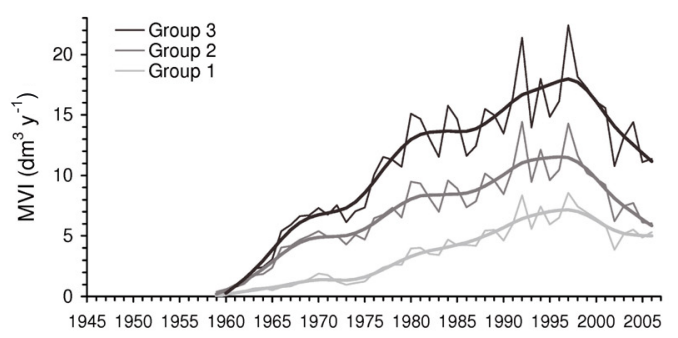

LOWER PLOT
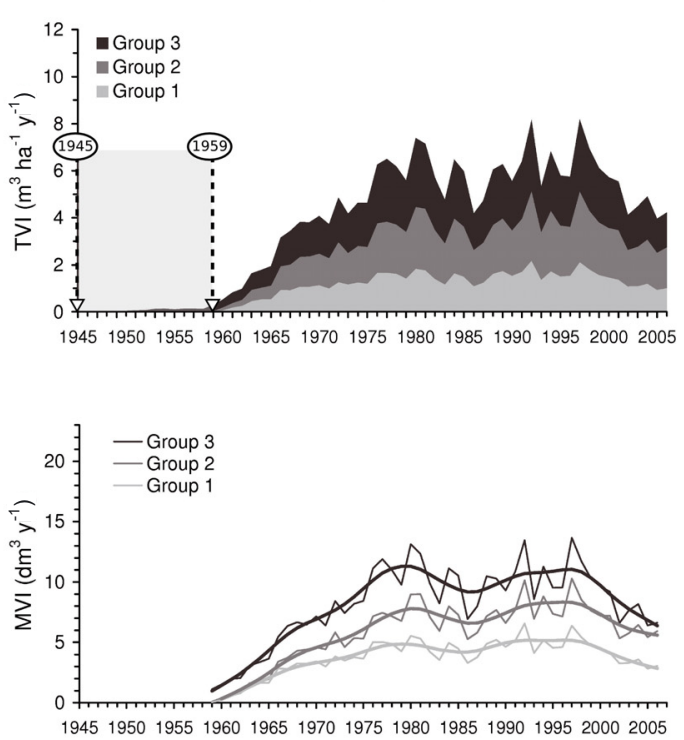

Figure 2. (a) Stand Total volume increment (TVI) as the sum of the three basal area groups total volume increment (TVIg) and (b) Mean Volume Increment (MVIg) for each basal area group. Thick lines are 11-y cubic smoothing splines. The vertical arrows show the year of coppicing in each plot.

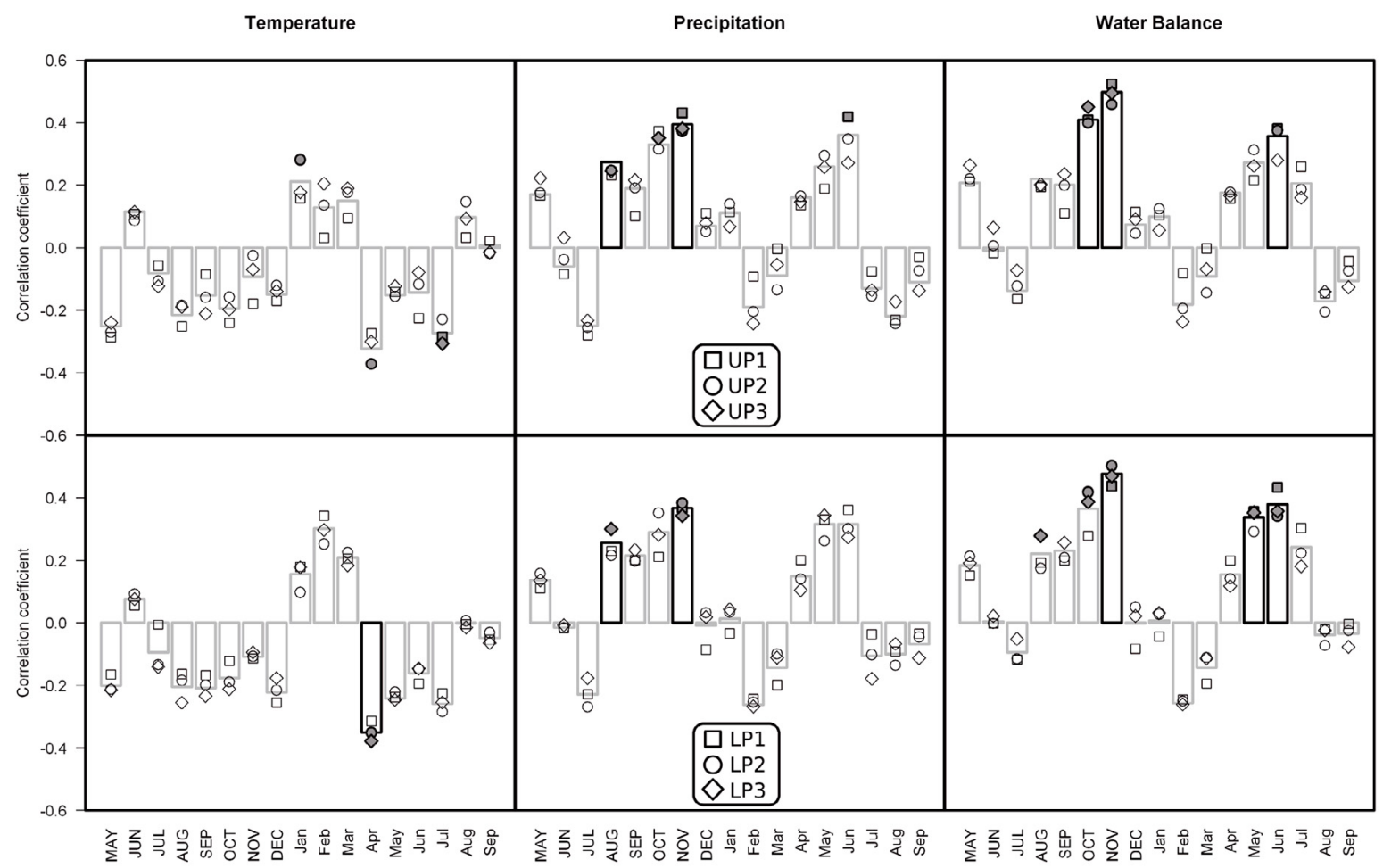

Figure 3. Correlation functions of mean volume increment prewhitened chronologies of all trees (bars) or basal area groups (circles) with monthly climatic variables. Computations refer to the period 1974-2006. Thicker bar borders and grey symbols show bootstrap correlations with $p<0.05$. UP: upper plot; LP: lower plot. Uppercase months on $x$-axis refer to the year preceding growth. 


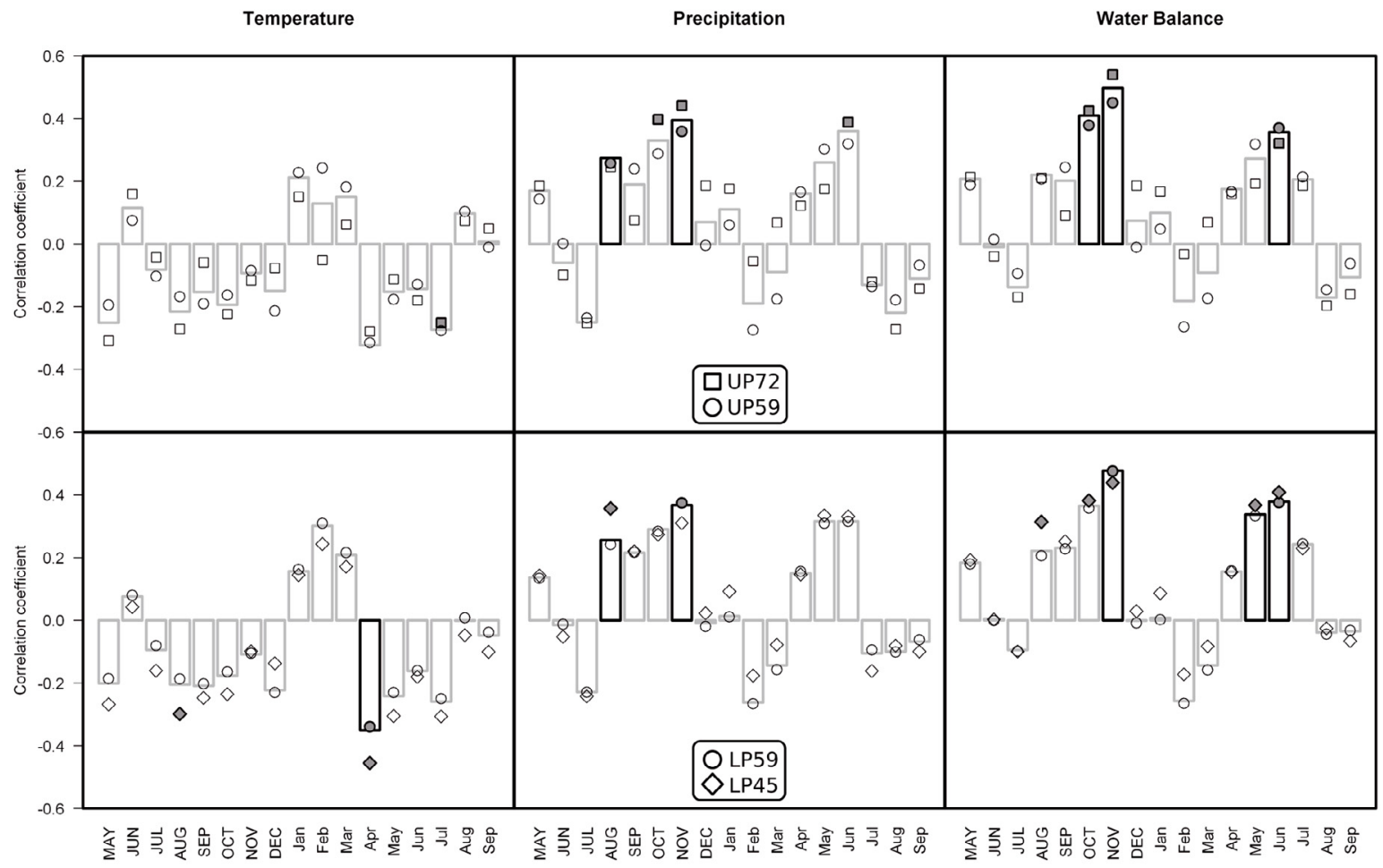

Figure 4. Correlation functions between mean volume increment chronologies of all trees in the study plot (bars) or for each cohort (circles) and monthly climatic variables for the period 1974-2006. Thicker bar borders and grey symbols show bootstrap correlations with $p<0.05$. UP: upper plot; LP: lower plot. Uppercase months on $x$-axis refer to the year preceding growth.

reached significant values. Single month MCFs and MRFs confirmed the trends observed in grouped variables (data not shown). During 1994-2006, a lagged response appeared to June water balance of two years before, suggesting that loss of current-year climate signals was accompanied by increased dependence on previous-year ones. This response was observed throughout different levels of structural organization (BA groups, cohorts) of the two coppices. The Manziana BAI chronology was influenced by similar factors (Fig. 5), with the exception of the two-year prior June signal, most likely because trees were sampled in 2001.

Good agreement was found between VI chronologies not only at the annual timescale but also at the 11-y time scale. In particular, decadal oscillations were well synchronized among BA groups (Fig. 2b) as well as cohorts (Fig. 6a), underlining the existence of a common climatic control even at multiannual time scales. The 1945 and 1959 cohorts showed a first growth peak at the beginning of the 1980s, a decrease in the mid-1980s, a second peak in the mid 1990s, and a decline after 1997. The 1959 and 1972 cohorts at the upper plot (UP59 and UP72) increased their productivity (with minor oscillations) until 1997. On the other hand, cohort productivity at the lower plot, last cut in 1959, stabilized at the end of the 1970s. While LP59 increased its growth when reaching the second peak in the 1990s, for the older LP45 this second peak was lower than the first one. Thus, both age structure and coppice history controlled decadal stand productivity.

Instability of climate-growth relationships made it difficult to find a unique climatic signal for decadal productivity oscillations. Results from 11-y MCF/MRF analyses showed that VI variations were better explained by grouped climatic variables than monthly ones (data not shown). Nonetheless, the first VI peak for 1945 and 1959 cohorts occurred during the beginning of the 1980s together with favorable May-June water balance levels (Figs. 7a, 7b). Afterwards, May-June water balance two years prior seemed to control VI by leading it to the 1997 culmination and to the present-day decline, especially in the 1959 cohorts. The older Manziana high forest confirmed even at decadal scales to be similar to the two Monte Piantangeli coppices (Fig. S3), with a relationship between productivity and current May-June water balance that began in the 1960s (Fig. 7c).

\section{DISCUSSION}

Our results provide evidence that growth and productivity of deciduous oaks in Mediterranean environments is coupled to the hydrologic balance, in particular to precipitation in late spring-early summer as well as the previous autumn (e.g. Romagnoli and Codipietro, 1996). On a year-to-year 

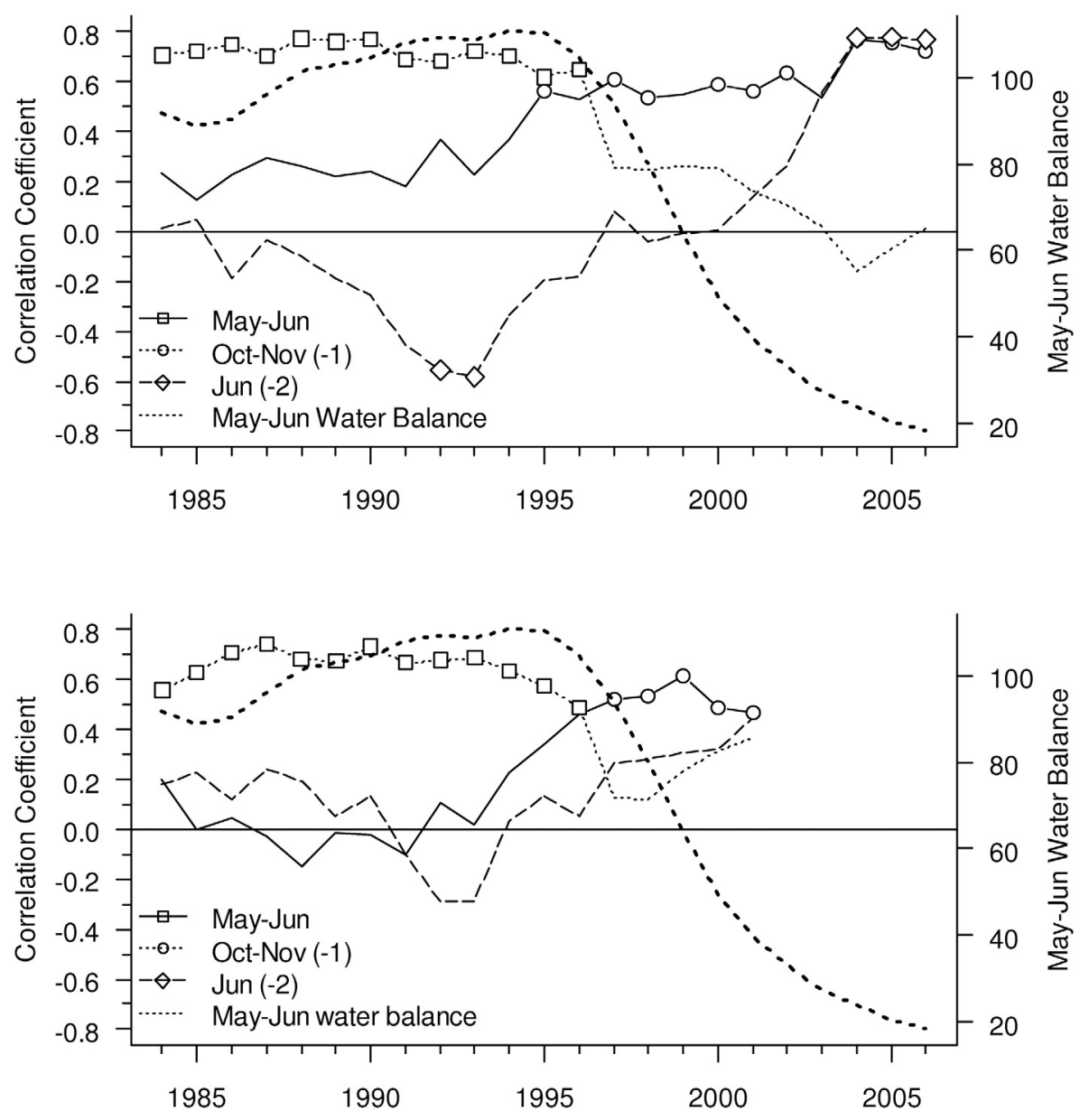

Figure 5. 11-y Moving Correlation Function (MCF) of LP59 volume increment (above) and the BAI of Quercus cerris from the Manziana high-forest (below) with selected climatic factors. Each value represent the last year of each interval. Symbols upon each line denote 11-y intervals with bootstrap correlation $p<0.05$. Dotted line: May-June water balance 11-y spline.

scale, these climatic signals were found in chronologies of ring width, basal area increment, and volume increment, in agreement with a previous study of Turkey oak in central Italy (Corona et al., 1995). While the May-June signal represents the direct limiting effect of growing season drought, the previous autumn relationship could be linked to soil water recharge, utilization of accumulated reserves, and/or root activity (e.g. Lebourgeois et al., 2004). Water requirements during the summer are typical of deciduous oaks even in environments that are considerably wetter than those we studied (Čufar et al., 2008; Drobyshev et al., 2008; Friedrichs et al., 2009; Helama et al., 2009; Lebourgeois, 2006; Tardif et al., 2006).

Stem age and logging history affect decadal tree productivity response to climate (e.g. Rozas, 2005; Voelker et al., 2008), but climate can in turn exert a strong, synchronizing influence on growth of stands with very different structure and management history. In fact, growth and productivity of stems with different size, age, and sociological status fluctuated similarly. A consistent climatic response among cohorts of different ages or stems of various sizes was previously reported for Pinus contorta (Chhin et al., 2008) and Picea abies
(Meyer and Bräker, 2001), in contrast with other studies of the same genera (Brakel and van den Visser, 1996; De Luis et al., 2009; Martín-Benito et al., 2008; Vieira et al., 2009). It is likely that coppices are characterized by a closer link between stems, for instance through root connections (anastomosis), making growth-climate relationships more homogeneous over a region. Furthermore, competition for water is symmetric (see the case of declining Betula maximowicziana, Ohno et al., 2009), hence it can synchronize growth rates among size classes and population cohorts. In our study, this mechanism would also explain the $\sim 30 \%$ reduction in productivity (about 2-3 $\mathrm{m}^{3} \mathrm{ha}^{-1} \mathrm{y}^{-1}$ ) experienced by stems of different size, age, and sociological status during the drought of the last decade.

May-June water balance is critical for phenology and auxology of deciduous oaks because of internal flow requirements for ring-porous wood (e.g. Corcuera et al., 2004; Zweifel et al., 2006). At the same time, late spring-early summer ring formation controls latewood width, responsible for variation in whole-year ring width (Akkemik et al., 2006; Corcuera et al., 2004). Given the greater risk of embolism in ring-porous oaks compared to ring-diffuse ones (e.g. Corcuera et al., 2004), 

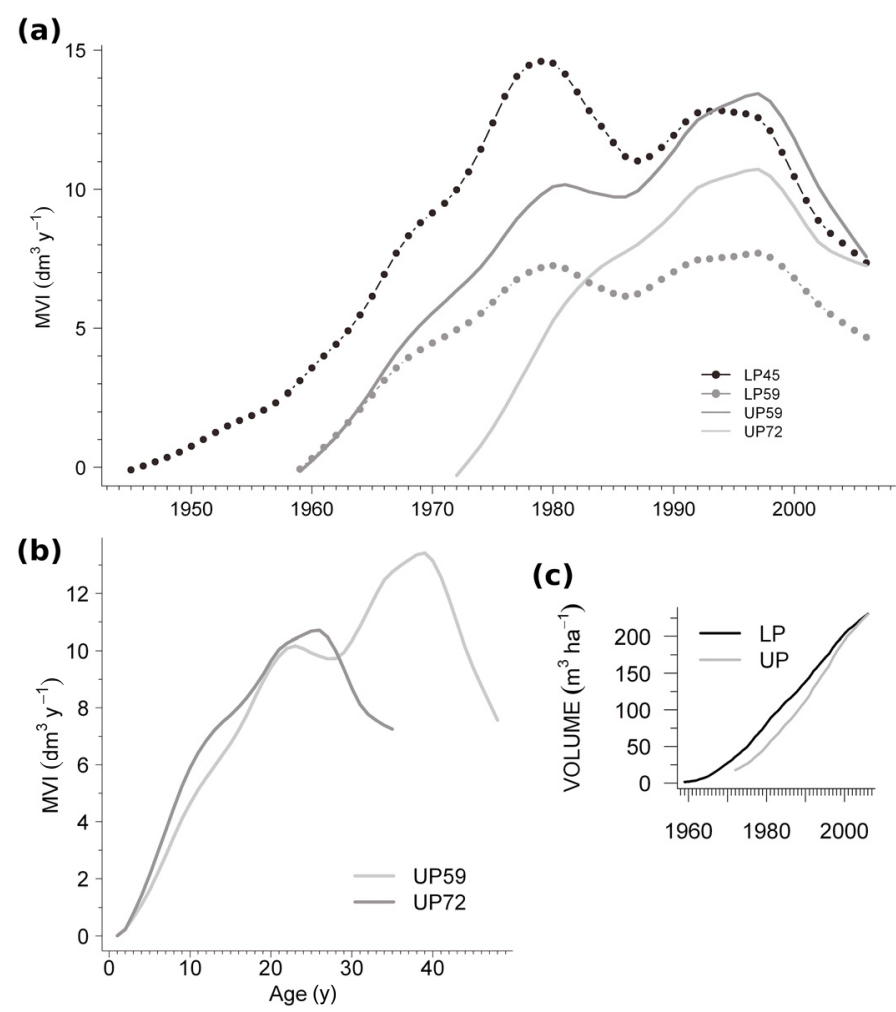

Figure 6. Mean volume increment (MVI) 11-y splines of (a) all cohorts as a function of time and (b) upper plot cohorts as a function of age (c) cumulated total volume increment since the last logging at upper (grey) and lower (black) plot.

May-June drought can increase cavitation, reduce crown vitality, and limit overall ring width, ultimately determining tree productivity at annual and decadal time scales regardless of sociological status or stem size and age.

The growth response to May-June water balance is not consistent over time, since it disappears in the late 1990s as the May-June water balance trend also decreases, approaching a zero value. The reduced sensitivity to summer drought during a dry spell suggests that stems become dormant, as it has already been observed in other Mediterranean forest species (e.g. Cherubini et al., 2003). Possibly a similar mechanism (see Weber et al., 2007) was responsible for the lack of correlation between July-August climatic variables and Turkey oak productivity (see Fig. 1). Overall, an increase in late springearly summer drought cancelled the related dendroclimatic signal, enhancing the response to previous year factors. In fact, during the 1990 s the main correlations are for previous autumn water balance. At the study area, November is the wettest month, and most likely soil water recharge is linked to precipitation during this month.

A previous autumn signal has been identified in other dendroclimatic studies of deciduous oaks, especially with regard to earlywood formation (Corcuera et al., 2004). A connection with underground processes, such as groundwater recharge, can be hypothesized because Turkey oak has a deep root system capable of lifting water from deep substrate materials so that it is also released into the upper soil layers, as a result of a water potential gradient, before it is reabsorbed by shallow roots and transpired by the crowns - a phenomenon known as "hydraulic lift" (David et al., 2007). This mechanism should reduce water stress also for ectomycorrhizal fungi, permitting their survival during drought (Lilleskov et al., 2009) and greater drought resistance of the tree (e.g. Mosca et al., 2007; Swaty et al., 2004). Autumn moisture can have a direct positive effect on root growth (Weber et al., 2007), so "when the new growth cycle begins, the following year, the tree will have a much larger root structure and will therefore be in a position to grow more" (Lebourgeois et al., 2004). Aboveground processes may also be involved, i.e. the formation of buds and the accumulation of carbon in C-stores (Barbaroux and Bréda, 2002).

In the most recent period (since about 1993), the positive response to June precipitation two years prior may be related to floral induction, since Turkey oak acorns mature over a twoyear period. Reproductive processes may reduce vegetative ones, to the extent of preceding the growth decline or even death of a tree (Piovesan and Adams, 2005; Hirayama et al., 2008). According to the "mast depression hypothesis", particularly intense reproduction can expose woody species to insect and parasite attacks (e.g. Selås et al., 2001), such as caterpillars, contributing to oak decline (see Marçais and Bréda, 2006).

In general, reduced xylem increment is strongly linked to forest decline episodes (Dobbertin, 2005; Standovár and Somogyi, 1998). In our study, at both annual and decadal timescales, peak volume growth and the decline that follows 


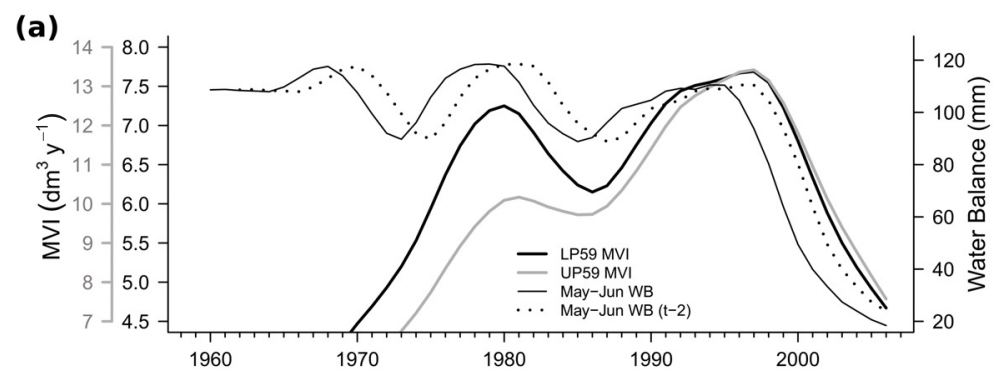

(b)

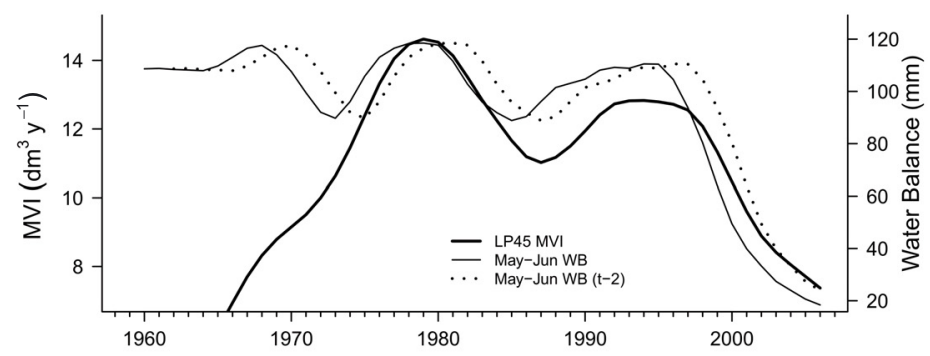

(c)

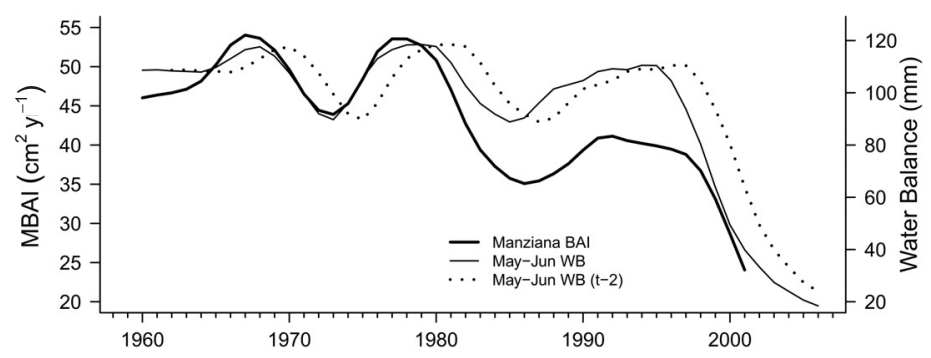

Figure 7. 11-y splines of the mean volume increment (MVI) or mean basal area increment (MBAI) matched to May-June water balance (WB) of current year $(t)$ and 2 years before present $(t-2)$. (a) Lower and upper plot 1959 cohort (LP59, UP59); the gray $y$-axis refers to UP59. (b) Lower plot 1945 cohort (LP45). (c) Mean BAI of Manziana Quercus cerris high-forest.

are associated with a delayed response to climate, with a lag of about two years, most likely driven by internal carbon balance, predetermined bud formation, and crown modification (Orwig and Abrams, 1997; Zweifel et al., 2006). In ring-porous oaks, earlywood cells originate before budburst so the anabolic activity for growth must be supported from internal C-stores formed in previous year(s) (Zweifel et al., 2006). Irreversible drought-induced damage usually leads to short term physiological disorders, like decreased carbon and nutrient assimilation, and sometimes even a breakdown of the photosynthetic machinery itself. These tissues have to be repaired before normal processes can resume (Breda et al., 2008), but drought only seldom results in direct and immediate induction of tree decline and mortality (Drobyshev et al., 2007; Pedersen, 1999).

Given the role of delayed effects of water shortages for oak growth decline (see Dwyer et al., 1995), its appearance in dendroecological responses could be used as an early warning signal. Another recent study on Pinus brutia indicated that, as moisture availability decreased, the highest correlations of tree growth with rainfall were obtained for progressively longer integration periods (from $1-2 \mathrm{y}$ in moist periods to 5-6 y during the actual severe drought), suggesting increasing dependency on deep soil water (Sarris et al., 2007). Endophytic attacks may therefore be favored by reduced formation of latewood and increased cavitation, allowing fungi to reach the cambium (Vannini et al., 2009). Climatic conditions that alternate from greatly favorable to unfavorable, as was the case from pre- to post-1997, have also been proposed as the trigger of forest growth decline in dense stands that experience high competition levels (e.g. McDowell et al., 2008).

Mediterranean stored coppices are destined to be affected by growth decline because drought generally occurs every decade (see also Corcuera et al., 2006). MCF/MRF were useful to link interannual to interdecadal climate-growth variations due to shifting dominant climatic signals throughout stand history. At the stand level, decadal climatic control over auxologic patterns implies that climate contributes to determining the potential growth of different cohorts (Dwyer et al., 1995; Voelker et al., 2008). In fact, a negative May-June water balance trend beginning in 1997 was most likely responsible for the increment of UP72 to culminate 15 y before that of UP59 (Fig. 6b). Older cohorts (from 1945 and 1959 logging events) began showing volume increments synchronous 
with water balance during a dry period in the 1980s, which influenced UP59 relatively less due to a lower stand density. Another coppice located at lower elevation than LP, but with similar age, also experienced a growth decline in the late 1980s mainly in suppressed and intermediate stems (Amorini et al., 1996).

\section{CONCLUSION}

We uncovered evidence that deciduous oak ecosystems recently exhibited a growth decline in Northern Latium following a regional increase in drought stress over the whole Mediterranean Basin. A similar trend has been documented for unmanaged beech (Fagus sylvatica L.) high-forests in southern Europe (Spain and Italy: Jump et al., 2006; Piovesan et al., 2008), Abies pinsapo in Spain (Linares et al., 2009) and Pinus halepensis in Greece (Sarris et al., 2007). In Central Italy, hilly and mountain beech stands showed, at a multidecadal (50 y) time-scale, 20-30\% productivity loss since peak growth in the 1970s (Piovesan et al., 2008). Historical changes in hydrologic balance can have different impacts on tree growth based on biogeographical and bioclimatic features because of different phenological rhythms (Di Filippo et al., 2007; Piovesan et al., 2005). For instance, in the Apennines, mountain forests dominated by European beech are particularly sensitive to summer drought later in the season than for Turkey oak coppice on hillsides at lower elevations. As elevation decreases, precipitation becomes more and more important compared to temperature for driving ecological changes (see Sarris et al., 2007). Since disturbance is the primary mechanism that changes ecosystems from carbon sinks to sources, monitoring oak dieback processes is an important step to understand climate-vegetation interactions with the carbon cycle (Running, 2008).

We demonstrated that management of old stored coppice and the models used to predict yield from forest stands need to rely not only on soil and climate average conditions (e.g. Pokharel and Froese, 2009), but also on climatic variability. Growth decline will probably continue to be a recurring problem for Mediterranean oak ecology, especially in protected areas where conservation priorities tend to increase population density and tree age. Uninterrupted observations of old coppice stands will allow knowing if productivity reduction leads to accelerated self-thinning without any further consequences, or to a mass dieback of entire populations. On the other hand, forest research will also be necessary to determine if old coppice stands that may be susceptible to growth decline should be managed to withstand these stresses (La Marca et al., 2009).

Acknowledgements: Funding was provided, in part, by research project PRAL Regione Lazio No. 2003/75. We wish to thank the students who helped in sample collection and measuring: G. Santarelli, G. Eusepi, F. Di Fulvio, and B. Ferrari. We also thank U. Chiocchini and F.A. Biondi for providing soil data, N. Anselmi for contributing important phytopathological insights, and M. Maugeri for supplying the climate data used in this paper. We thank the Handling Editor and two anonymous reviewers for their comments on a former version of the manuscript.

\section{REFERENCES}

Agrimi M., Ciancio O., Portoghesi L., and Pozzoli R., 1991. I querceti di cerro e farnetto di macchia grande di Manziana: struttura, trattamento e gestione. Cellulosa e Carta 49: 25-49.

Alessandrini A., Blasi S., Biondi F., Chiocchini U., Di Filippo A., Eusepi G., et al., 2008. Geopedologia e dendroauxoclimatologia di cedui di oltre turno. Alberi e Territorio. 6: 14-18.

Allen C.D., 2009. Climate-induced forest dieback: an escalating global phenomenon? Unasylva 60: 231-232.

Akkemik Ü., Çinar Yilmaz H., and Sevgl O., 2006. Cambial activity of the sessile oak (Quercus petraea) in Belgrade forest, Istanbul. Turkish Journal of Agriculture and Forestry 30: 429-438.

Amorini E., Biocca M., Manetti M.C., and Motta E., 1996. A dendroecological study in a declining oak coppice stand. Ann. For. Sci. 53: 731-742.

Anselmi N., Ferrari B., Nasini M., and Portoghesi L., 2008. Fitopatologia e selvicoltura di un bosco ceduo oltreturno. Alberi e Territorio 6: $19-22$.

Arrigoni P.V., 1998. La vegetazione forestale. Boschi e macchie di Toscana. Regione Toscana, Giunta Regionale, Firenze.

Barbaroux C. and Bréda N. 2002. Contrasting distribution and seasonal dynamics of carbohydrate reserves in stem wood of adult ring-porous sessile oak and diffuse-porous beech trees. Tree Physiol. 22: 12011210.

Bascietto M. and Scarascia-Mugnozza G., 2004. A collection of functions to determine annual tree carbon increment via stem-analysis. Ann. For. Sci. 61: 597-602.

Bianchi M. and La Marca O., 1984. I cedui di cerro nella provincia di Viterbo. Ricerche dendrometriche ed allometriche in relazione ad una ipotesi di matricinatura intensiva. Istituto di assestamento forestale dell'Università di Firenze, Ricerche Sperimentali di Dendrometria ed Auxometria 10: 41-70.

Biondi F., 1999. Comparing tree-ring chronologies and repeated timber inventories as forest monitoring tools. Ecol. Appl. 9: 216-227.

Biondi F. and Swetnam T.W., 1987. Box-Jenkins models of forest interior tree-ring chronologies. Tree-ring Bull. 47: 71-95.

Biondi F. and Waikul K., 2004. DENDROCLIM2002: a C++ program for statistical calibration of climate signals in tree-ring chronologies. Comput. Geosci. 30: 303-311.

Bouriaud O., Bréda N., Dupouey J.L., and Granier A., 2005. Is ring width a reliable proxy for stem-biomass increment? A case study in European beech. Can. J. For. Res. 35: 2920-2933.

Brakel J.A. and van den Visser H., 1996. The influence of environmental conditions on tree-ring series of Norway spruce for different canopy and vitality classes. For. Sci. 42: 206-219.

Bréda N., Huc R., Granier A., and Dreyer E., 2006. Temperate forest trees and stands under severe drought: a review of ecophysiological responses, adaptation processes and long-term consequences. Ann. For. Sci. 63: 625-644.

Brunetti M., Maugeri M., Monti F., and Nanni T., 2006. Temperature and precipitation variability in Italy in the last two centuries from homogenised instrumental time series. Int. J. Climatol. 26: 345-381.

Cherubini P., Gartner B.L., Tognetti R., Bräker O.U., Schoch W., and Innes J.L., 2003. Identification, measurement and interpretation of tree rings in woody species from Mediterranean climates. Biol. Rev. 78: 119-148.

Chhin S., Hogg E.H., Lieffers V.J., and Shongming H., 2008. Potential effects of climate change on the growth of lodgepole pine across diameter size classes and ecological regions. For. Ecol. Manage. 256: 1692-1703.

Ciancio O. and Nocentini S., 2004. Il bosco ceduo: selvicoltura, assestamento, gestione, Accademia Scienze Forestali, Firenze. 
Claps P., Giordano P., and Laguardia G., 2008. Spatial distribution of the average air temperatures in Italy: quantitative analysis. J. Hydrol. Eng. 13: 242-249.

Cook E.R. and Peters K., 1981. The smoothing spline: a new approach to standardizing forest interior tree-ring width series for dendroclimatic studies. Tree-ring Bull. 41: 45-53.

Cook E.R. and Holmes R.L., 1986. Users Manual for Program ARSTAN, Laboratory of Tree-Ring Research, University of Arizona, Tucson, USA.

Cook E.R. and Kairiukstis L.A., 1990. Methods of Dendrochronology: Applications in Environmental Science, Kluwer Academic Publishers, Dordrecht, pp. 104-123.

Corcuera L., Camarero J.J., and Gil-Pelegrin E., 2004. Effects of a severe drought on growth and wood-anatomical properties of Quercus faginea. IAWA J. 25: 185-204.

Corcuera L., Camarero J.J., Sisó S., and Gil-Pelegrın E., 2006. Radialgrowth and wood-anatomical changes in overaged Quercus pyrenaica coppice stands: functional responses in a new Mediterranean landscape. Trees 20: 91-98.

Corona P., Romagnoli M., and Torrini L., 1995. Stem annual increments as ecobiological indicators in Turkey oak (Quercus cerris L.). Trees 10: $13-19$.

Čufar K., de Luis M., Eckstein D., and Kajfež-Bogataj L., 2008. Reconstructing dry and wet summers in SE Slovenia from oak treering series. Int. J. Biometeorol. 52: 607-615.

David T.S., Henriques M.O., Kurz-Besson C., Nunes J., Valente F., Vaz M., et al., 2007. Water-use strategies in two co-occurring Mediterranean evergreen oaks: surviving the summer drought. Tree Physiol. 27: 793-803.

De Luis M., Novak K., Čufar K., and Raventós J., 2009. Size mediated climate-growth relationships in Pinus halepensis and Pinus pinea. Trees 23: $1065-1073$.

Desprez-Loustau M.L., Marçais B., Nageleisen L.M., Piou D., Vannini A., 2006. Interactive effects of drought and pathogens in forest trees. Ann. For. Sci. 63: 597-612.

Di Filippo A., Biondi F., Cufar K., de Luis M., Grabner M., Maugeri M., et al., 2007. Bioclimatology of beech (Fagus sylvatica L.) in the Eastern Alps: spatial and altitudinal climatic signals identified through a tree-ring network. J. Biogeogr. 34: 1873-1892.

Dittmar C., Fricke W., and Elling W., 2006. Impact of late frost events on radial growth (Fagus sylvatica L.) in Southern Germany. Eur. J. For. Res. 125: 249-259.

Dobbertin M., 2005. Tree growth as indicator of tree vitality and of tree reaction to environmental stress: a review. Eur. J. For. Res. 124: 319333.

Drobyshev I., Linderson H., and Sonesson K., 2007. Temporal mortality pattern of pedunculate oaks in southern Sweden. Dendrochronologia 24: 97-108.

Drobyshev I., Niklasson M., Eggertsson O., Linderson H., and Sonesson K., 2008. Influence of annual weather on growth of pedunculate oak in southern Sweden. Ann. For. Sci. 65: 512.

Dwyer J.P., Cutter B.E., and Wetteroff J.J., 1995. A dendrochronological study of black and scarlet oak decline in the Missouri Ozarks. For. Ecol. Manage. 75: 69-75.

Efron B. and Tibshirani R., 1986. Bootstrap methods for standard errors, confidence intervals, and other measures of statistical accuracy. Stat. Sci. 1: 54-75.

Friedrichs D.A., Büntgen U., Frank D.C., Esper J., Neuwirth B., and Löffler J., 2009. Complex climate controls on 20th century oak growth in Central-West Germany. Tree Physiol. 29: 39-51.

Guiot J., 1991. The bootstrapped response function. Tree-ring Bull. 51: $39-41$.
Helama S., Läänelaid A., Raisio J., and Tuomenvirta H., 2009. Oak decline in Helsinki portrayed by tree-rings, climate and soil data. Plant Soil 319: 163-174.

Hirayama D., Nanami S., Itoh A., and Yamakura T., 2008. Individual resource allocation to vegetative growth and reproduction in subgenus Cyclobalanopsis (Quercus, Fagaceae) trees. Ecol. Res. 23: 451-458.

Hurrell J.W., 1995. Decadal trends in the North Atlantic oscillations: regional temperatures and precipitation. Science 269: 676-679.

Kahle H.P., Karjalainen T., Schuck A., Ågren G.I., Kellomäki S., Mellert K.H., et al., 2008. Causes and consequences of forest growth trends in Europe. European Forest Institute Research Report 21 - Result of the RECOGNITION Project. Brill, Leiden.

Kirilenko A.P. and Sedjo R.A., 2007. Climate change impacts on forestry. PNAS 104: 19697-19702.

Jump A.S., Hunt J.M., and Peñuelas J., 2006. Rapid climate changerelated growth decline at the southern range edge of Fagus sylvatica. Glob. Change Biol. 12: 2163-2174.

La Marca O., 2004. Elementi di dendrometria. Patron Editore, Padova, Italy.

La Marca O., Scopigno D., Tomaiuolo M., 2009. Primi risultati in prove di avviamento in un ceduo misto del Gargano. Forest@ - Rivista di Selvicoltura ed Ecologia Forestale. 6: 120-128.

LeBlanc D., 1990. Relationships between breast-height and whole stem growth indices for red spruce on Whiteface Mountain, New York. Can. J. For. Res. 20: 1399-1407.

Lebourgeois F., Cousseau G., and Ducos Y., 2004. Climate-tree-growth relationships of Quercus petraea Mill. stand in the Forest of Bercé ("Futaie des Clos", Sarthe, France). Ann. For. Sci. 61: 361-372.

Lebourgeois F., 2006. Sensibilité au climat des Chênes sessile et pédonculé dans le réseau RENECOFOR. Comparaison avec les hêtraies. Rev. For. Fr. 58: 29-44.

Lilleskov E.A., Bruns T.D., Dawson T.E., and Camacho F.J., 2009. Water sources and controls on water-loss rates of epigeous ectomycorrhizal fungal sporocarps during summer drought. New Phytol. 182: 483494.

Linares J.C., Delgado-Huertas A., Camarero J.J., Merino J., and Carreira J.A., 2009. Competition and drought limit the response of water-use efficiency to rising atmospheric carbon dioxide in the Mediterranean fir Abies pinsapo. Oecologia 161: 611-624.

Marçais B. and Bréda N., 2006. Role of an opportunistic pathogen in the decline of stressed oak trees. J. Ecol. 94: 1214-1223.

Mariotti A., Ballabrera-Poy J., and Zeng N., 2005. Tropical influence on Euro-Asian autumn rainfall variability. Clim. Dyn. 24: 511-521.

Mariotti A., Zeng N., Yoon J.H., Artale V., Navarra A., Alpert P., et al., 2008. Mediterranean water cycle changes: transition to drier $21 \mathrm{st}$ century conditions in observations and cmIP3 simulations. Environ. Res. Lett. 3: 044001.

Martín-Benito D., Cherubini P., del Río M., and Cañellas I., 2008. Growth response to climate and drought in Pinus nigra Arn. trees of different crown classes. Trees 22: 363-373.

McCabe G.J. and Markstrom S.L., 2007. A monthly water-balance model driven by a graphical user interface. US Geological Survey Open-File report 2007.

McDowell N., Pockman W.T., Allen C.D., Breshears D.D., Cobb N., Kolb T., et al., 2008. Mechanisms of plant survival and mortality during drought: why do some plants survive while others succumb to drought? New Phytol. 4: 719-739.

Metsaranta J.M. and Lieffers V.J., 2009. Using dendrochronology to obtain annual data for modelling stand development: a supplement to permanent sample plots. Forestry 82: 163-173.

Meyer F.D. and Bräker O.U., 2001. Climate response in dominant and suppressed spruce trees, Picea abies (L.) Karst., on a subalpine and lower montane site in Switzerland. Ecoscience 8: 105-114. 
Mosca E., Montecchio L., Sella L., and Garbaye J., 2007. Short-term effect of removing tree competition on the ectomycorrhizal status of a declining pedunculate oak forest (Quercus robur L.). For. Ecol. Manage. 244: 129-140.

Nahm M., Radoglou K., Halyvopoulos G., Geßler A., Rennenberg H., and Fotelli M.N., 2006. Physiological performance of beech (Fagus sylvatica L.) at its Southeastern distribution limit in Europe: seasonal changes in nitrogen, carbon and water balance. Plant Biol. 8: 52-63.

Nogués Bravo D., Araújo M.B., Lasanta T., and López Moreno J.I., 2008. Climate change in Mediterranean mountains during the 21st Century. Ambio, 37: 280-285.

Ohno Y., Umeki K., Watanabe I., Takiya M., Terazawa K., Yasaka M., et al., 2009. Basal area growth and mortality of Betula maximowicziana affected by crown dieback in a secondary forest in Hokkaido, northern Japan. J. For. Res. 14: 37-43.

Orwig D.A. and Abrams M.D., 1997. Variation in radial growth responses to drought among species, site, and canopy strata. Trees 11: 474-484.

Parry M., Palutikof J., Hanson C., and Lowe J., 2008. Squaring up to reality. Nature reports climate change, 2, 68-70. URL http://www. nature.com/reports/climatechange.

Pedersen B.S., 1999. The mortality of Midwestern overstory oaks as a bioindicator of environmental stress. Ecol. Appl. 9: 1017-1027.

Piovesan G. and Schirone B., 2000. Winter North Atlantic Oscillation effects on the tree rings of the Italian beech (Fagus sylvatica L.). Int. J. Biometeorol. 44: 121-127.

Piovesan G. and Adams J.M., 2005. The evolutionary ecology of masting: does the environmental prediction hypothesis also have a role in mesic temperate forests? Ecol. Res. 20: 739-743.

Piovesan G., Biondi F., Bernabei M., Di Filippo A., and Schirone B., 2005. Spatial and altitudinal bioclimatic zones of the Italian peninsula identified from a beech (Fagus sylvatica L.) tree-ring network. Acta Oecol. 27: 197-210.

Piovesan G., Biondi F., Di Filippo A., Alessandrini A., and Maugeri M., 2008. Drought-driven growth reduction in old beech (Fagus sylvatica) forests of the central Apennines, Italy. Glob. Change Biol. 14: $1-17$.

Planchon O., Dubreuil V., Bernard V., and Blain S., 2008. Contribution of tree-ring analysis to the study of droughts in northwestern France (XIX-XXth century). Clim. Past Discussions 4: 249-270. URL http://www.clim-past-discuss.net/4/249/2008/

Plutino M., 2006. Struttura e dinamica evolutiva dei boschi in stato di abbandono gestionale: il caso delle fustaie di cerro nell'Alto Lazio. $\mathrm{Ph} . D$. Thesis, University of Tuscia, http://dspace.unitus.it/dspace/ handle/2067/567.

Pokharel B. and Froese R.E., 2009. Representing site productivity in the basal area increment model for FVS-Ontario. For. Ecol. Manage. 258: 657-666.

R Development Core Team, 2005. R: a language and environment for statistical computing, reference index version 2.2.1. R Foundation for Statistical Computing, Vienna, Austria. ISBN 3-900051-07-0, URL http://www.R-project.org.

Ragazzi A., Moricca S., Turco E., and Dellavalle I., 2002. Dendroclimatic analysis of Quercus robur infected with Fusarium eumartii. Phytopathol. Mediterr. 41: 131-137.

Romagnoli M. and Codipietro G., 1996. Pointer years and growth in Turkey oak (Quercus cerris L) in Latium (central Italy). A dendroclimatic approach. Ann. Sci. For. 53: 671-684.

Rosenzweig C., Karoly D., Vicarelli M., Neofotis P., Wu Q., Casassa G., et al., 2008. Attributing physical and biological impacts to anthropogenic climate change. Nature 453: 353-357.
Rozas V., 2005. Dendrochronology of pedunculate oak (Quercus robur L.) in an old-growth pollarded woodland in northern Spain: tree-ring growth responses to climate. Ann. For. Sci. 62: 209-218.

Running S.W., 2008. Climate change: ecosystem disturbance, carbon, and climate. Science 321: 652-653.

Salter P.J. and Williams J.B., 1967. The influence of texture on the moisture characteristics of soils. A method of estimating the availablewater capacities of profiles in the field. Eur. J. Soil Sci. 18: 174-181.

Sarris D., Christodoulakis D., and Körner C., 2007. Recent decline in precipitation and tree growth in the eastern Mediterranean. Glob. Change Biol. 13: 1187-1200.

Schröter D., Cramer W., Leemans R., et al., 2005. Ecosystem service supply and vulnerability to global change in Europe. Science 5752: 1333-1337.

Selås V., Hogstad O., Andersson G., and Von Proschwitz T., 2001. Population cycles of autumnal moth, Epirrita autumnata, in relation to birch mast seeding. Oecologia, 129: 213-219.

Standovár T. and Somogyi Z., 1998. Corresponding patterns of site quality, decline and tree growth in a sessile oak stand. Eur. J. For. Pathol. 28: $133-144$.

Stokes M.A. and Smiley T.L., 1996. An introduction to tree-ring dating. Reprint of 1968 U. of Chicago Press ed. University of Arizona Press, Tucson, USA.

Swaty R.L., Deckert R.J., Whitham T.G., and Gehring C.A., 2004. Ectomycorrhizal abundance and community composition shifts with drought: predictions from tree rings. Ecology 85: 1072-1084.

Tardif J.C., Conciatori F., Nantel P., and Gagnon D., 2006. Radial growth and climate responses of white oak (Quercus alba) and northern red oak (Quercus rubra) at the northern distribution limit of white oak in Quebec, Canada. J. Biogeogr. 33: 1657-1669.

Van Mantgem P.J., Stephenson N.L., Byrne J.C., Daniels L.D., Franklin J.F., Fulé P.Z., et al., 2009. Widespread increase of tree mortality rates in the Western United States. Science 323: 521-524.

Vannini A. and Valentini R., 1994. Influence of water relations on Quercus cerris-Hypoxylon mediterraneum interaction: a model of drought-induced susceptibility to a weakness parasite. Tree Physiol. 14: 129-139.

Vannini A., Lucero G., Anselmi N., and Vettraino A.M., 2009. Response of endophytic Biscogniauxia mediterranea to variation in leaf water potential of Quercus cerris. For. Pathol. 39, 8-14.

Vieira J., Campelo F., and Nabais C., 2009. Age-dependent responses of tree-ring growth and intra-annual density fluctuations of Pinus pinaster to Mediterranean climate. Trees, 23: 257-265.

Voelker S.L., Muzika R.S., and Guyette R.P., 2008. Individual tree and stand level influences on the growth, vigor, and decline of Red oaks in the Ozarks. For. Sci. 54: 8-20.

Weber P., Bugmann H., and Rigling A., 2007. Radial growth responses to drought of Pinus sylvestris and Quercus pubescens in an innerAlpine dry valley. J. Veg. Sci. 18: 777-792.

Wigley T.M.L., Briffa K.R., and Jones P.D., 1984. On the average value of correlated time series, with applications in dendroclimatology and hydrometeorology. J. Appl. Meteorol. 23: 201-213.

Zweifel R., Zimmermann L., Zeugin F., and Newbery D.M., 2006. Intraannual radial growth and water relations of trees: implications towards a growth mechanism. J. Exp. Bot. 57: 1445-1459. 